\section{Water Treatment through Mwcnt Nanomembranes}

\author{
Christian M Argueta and Jorge I Cifuentes* \\ School of Mechanical Engineering and Engineering Research Center, \\ University of San Carlos of Guatemala, Guatemala
}

\begin{abstract}
In this research, a simple application of carbon nanotubes to filtrate water is explained. Nanomembranes were assembled using Mwcnt and cotton to create a mesh and fiber support to remove pollutants and meet the World Health Organization (WHO) parameters for drinking water. After the nanofiltration process the following results were obtained: Escherichia Coli was reduced from 6.8 per $100 \mathrm{ml}$ to 2.0 per $100 \mathrm{ml}$, Turbidity obtained after nanofiltration was reduced from 4.04 to $0.23 \mathrm{mg} / \mathrm{l}$; Magnesium content was reduced from $93.14 \mathrm{mg} / \mathrm{l}$ to $13.62 \mathrm{mg} / \mathrm{l}$, total hardness was reduced from 450 $\mathrm{mg} / \mathrm{l}$ to $132 \mathrm{mg} / \mathrm{l}$, the color diminished from 58 units to 1.0 units, $\mathrm{Ph}$ got reduced from 6.87 to 6.44 . The results show that the quality of water can be improved using multi wall carbon nanotubes to meet drinking water requirements. In addition, electric current was used through membranes to create electro separation of pollutants and let filtrated water to pass. The results also showed water with fewer pollutants and less turbidity after the nano filtration process. This is an approach in the use of nanotechnology for waste water treatment and increase the access to drinking water to more people around the World. This research was performed at School of mechanical engineering and engineering research center from University of San Carlos of Guatemala.
\end{abstract}

Keywords: Coliform germs; Electrodeposition; Filtration; Nanomaterials; Nanotubes

*Corresponding author: Jorge I Cifuentes, School of Mechanical Engineering and Engineering Research Center, University of San Carlos of Guatemala, Guatemala, Tel: +502 2418 9133; E-mail: jicifuentes@ing.usac.edu.gt

Citation: Cifuentes JI, Argueta CM (2018) Water Treatment through Mwcnt Nanomembranes. J Nanotechnol Nanomed Nanobiotechnol 5: 021.

Received: July 18, 2018; Accepted: October 25, 2018; Published: November 09, 2018

Copyright: ( 2018 Cifuentes $\mathrm{JI}$ and Argueta CM. This is an open-access article distributed under the terms of the Creative Commons Attribution License, which permits unrestricted use, distribution, and reproduction in any medium, provided the original author and source are credited.

\section{Introduction}

Water is the most precious element of human life and all forms of life. In recent years, new technologies have emerged worldwide for filtration, purification and treatment of contaminants in water for example, ultraviolet light, reverse osmosis, membrane technology, activated carbon, polymerization, purification treatment of wastes and contaminants in water and more recently the application of nanomembranes technology into the filtration process [1]. Researchers have been conducted by Rusnano with cotton and carbon nanotubes, testing nanomembranes for filtration and separation of biological pollutants in water, NASA researches were performed in the United States through the NanoCeram TM Corporation has used nano ceramic filtration systems at the space station [2,3].

\section{Carbon Nanotubes (CNTs)}

A carbon nanotube basically is a tube-shaped molecule made by carbon atoms. CNTs have a longitude of approximately one millimeter but new studies have been performed to develop longer nanotubes $[4,5]$. For this study Multi Wall Carbon Nanotubes (MWCNT) were used to fabricate the nanomembranes.

\section{Electrodeposition}

It is the application of a metal coating to a metallic or other conducting surface like carbon nanotubes by an electrochemical process. The process needs a cathode and an anode. The cathode (negative electrode) is immersed in an aqueous solution which contains the required metal in an oxidized form [6]. The anode is usually a piece of the metal being plated [7]. Components are electroplated to alter their appearance, to provide a protective coating to give the component special surface properties and to give engineering or mechanical properties [8].

This research was performed under the norm "COGUANOR NGO 29001 " which contains markers and parameters to have optimal potable water [9].

\section{Mwent Membranes and General Assembly}

The carbon nanotubes used in this study were multiple wall nanotubes, Mwcnt. It also was used a glass container, cotton pads rubbing alcohol, aluminum strainer with a copper wire to conduct electricity, two $9 \mathrm{v}$ batteries, alligator clips, wooden craft sticks, plastic funnel and copper wires.

Figure 1 shows the placement of all the components in a diagram. The cotton pads were moistened with rubbing alcohol and filled with Mwcnt to create membranes the Mwcnt gives the membrane the capacity to conduct electricity.

\section{The bottom of the funnel was filled with three layers be- fore place the cotton membrane, in the following way:}

From bottom to top a cotton pad a thick layer of Mwent acting as nano filter and membrane and another cotton pad. The plastic funnel is placed into the glass container to continue with the process. 


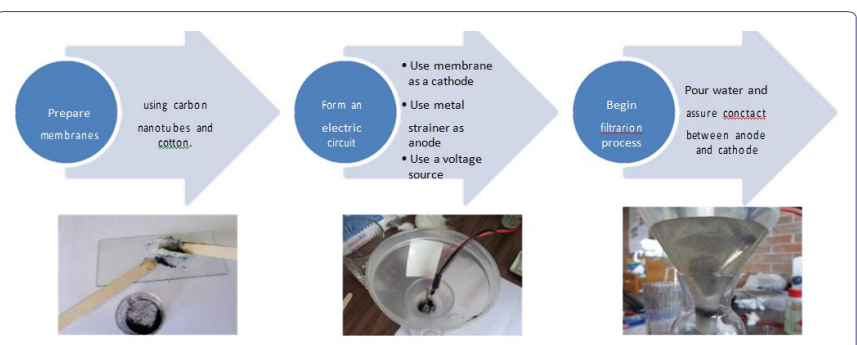

Figure 1: Fabrication process diagram.

With the membranes ready a copper wire was connected to it using an alligator clip and then placed it above the three-layer membrane detailed before, as shown in figure 2 . This step is very important because the cotton and Mwent act as a membrane and they should restrict the passage of water to act as a filter.

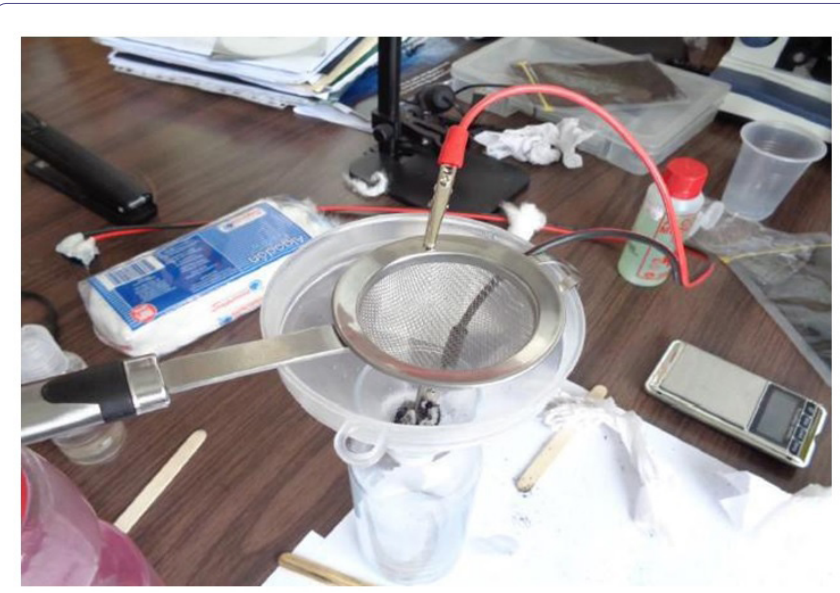

Figure 2: Nickel mesh, Mwcnt nanomembrane and electrical cables for electroseparation.

Later the aluminum strainer is attached with an alligator clip to a copper wire, as shown in figure 3 and then attached to the top of the funnel taking care to leave a space between the strainer and the membrane.
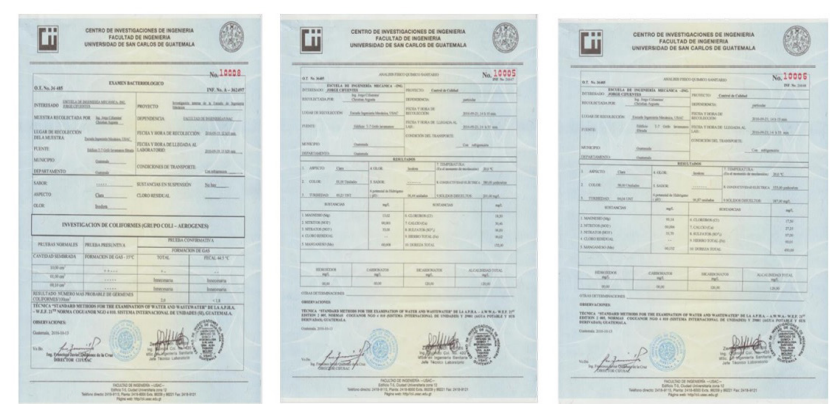

Figure 3: Laboratory test certificates.

The two wires were connected to a pair of $9 \mathrm{v}$ batteries which at that time had $9.48 \mathrm{v}$ in total. The tap water was poured into the funnel. The water acted as a conductor between the conducting membrane containing Mwent and the aluminum strainer both connected individually to the batteries.

In this process while the water was energized the Mwcnt acted as the cathode and the strainer as the anode. Most of the contaminants that were present in the water got attached to the nanotubes by the same principle of electrodeposition.

\section{Results and Discussion}

Based on the laboratory test certificates shown in figure 3 the tap water without any treatment showed a physiochemical and bacteriological analysis with several downsides; being the most important the high number of coliform germs. This had a value of 6.8 coliform germs $/ 100 \mathrm{~cm} 3$. The acceptable value for coliform germs based on the norm COGUANOR NGO 4010 , is $<1.8$ germs $/ 100 \mathrm{~cm}^{3}$ (ISO COGUANOR NGO 4 010) (COGUANOR NTG 29001, drinking water).

After the treatment using nanotubes, the number of coliform germs decreased to a value of 2 coliform germs $/ 100 \mathrm{~cm}^{3}$, as shown in table 1 which is still greater than an acceptable value. Also, the presumptive and confirmatory tests improved, as shown in tables 2 and 3 .

\begin{tabular}{|c|c|}
\hline & Pathogenic Escherichia coli / total/100 $\mathbf{~ m l}$ \\
\hline Before nano filtration & 6.8 \\
\hline After Mwcnt nano membranes filtration & 2.0 \\
\hline
\end{tabular}

Table 1: E Coli before and after nano membranes filtration per100 $\mathrm{ml}$.

\begin{tabular}{|c|c|c|c|}
\hline \multirow{2}{*}{ Normal test } & \multirow{2}{*}{ Presumptive test } & \multicolumn{2}{|c|}{ Confirmative test } \\
\cline { 2 - 4 } & Gas Formation \\
\hline Sown quantity & $\begin{array}{c}\text { Gas formation }-35 \\
\text { Celsius degrees }\end{array}$ & total & $\begin{array}{c}\text { Fecal }-44.5 \\
\text { Celsius degrees }\end{array}$ \\
\hline $10,00 \mathrm{~cm}^{3}$ & +++++ & ++--- & $-\ldots-$ \\
\hline $01,00 \mathrm{~cm}^{3}$ & ++-- & +- & -- \\
\hline $00,10 \mathrm{~cm}^{3}$ & ---- & unnecessary & unnecessary \\
\hline
\end{tabular}

Table 2: Bacteriological analysis results before filtration.

\begin{tabular}{|c|c|c|c|}
\hline \multirow{2}{*}{ Normal test } & Presumptive test & \multicolumn{2}{|c|}{ Confirmative test } \\
\cline { 2 - 4 } & Gas Formation \\
\hline Sown quantity & $\begin{array}{c}\text { Gas formation }-35 \\
\text { Celsius degrees }\end{array}$ & total & $\begin{array}{c}\text { Fecal }-44.5 \\
\text { Celsius degrees }\end{array}$ \\
\hline $10,00 \mathrm{~cm}^{3}$ & ++-- & +- & -- \\
\hline $01,00 \mathrm{~cm}^{3}$ & $-\cdots--$ & unnecessary & unnecessary \\
\hline $00,10 \mathrm{~cm}^{3}$ & $-\cdots--$ & unnecessary & unnecessary \\
\hline \multicolumn{3}{|r}{ Table 3: Bacteriological analysis results after filtration. } \\
\hline
\end{tabular}

In table 4, all the physicochemical parameters that were improved are shown.

The number of coliform germs could be better but different factors affected the experiment during the process. An example of these factors was that the membrane was not secured properly and the water passed too quickly through it avoiding the treatment. 


\begin{tabular}{|c|c|c|}
\hline Water pollutants & Before filtration & After filtration \\
\hline Total coliforms & $6.8 \mathrm{per} 100 \mathrm{ml}$ & $2.0 \mathrm{per} 100 \mathrm{ml}$ \\
\hline $\mathbf{p H}$ & $6.87 \mathrm{mg} / 1$ & $6.44 \mathrm{mg} / 1$ \\
\hline Turbidity & $4.04 \mathrm{mg} / 1$ & $0.23 \mathrm{mg} / 1$ \\
\hline Total hardness & $450 \mathrm{mg} / 1$ & $132 \mathrm{mg} / 1$ \\
\hline Color & $58 \mathrm{units}$ & $1.0 \mathrm{unit}$ \\
\hline Magnesium & $93.14 \mathrm{mg} / 1$ & $13.62 \mathrm{mg} / 1$ \\
\hline chlorides & $18.5 \mathrm{mg} / 1$ & $17.50 \mathrm{mg} / 1$ \\
\hline Calcium & $30.46 \mathrm{mg} / 1$ & $27.25 \mathrm{mg} / 1$ \\
\hline Sulfates & $7.0 \mathrm{mg} / 1$ & $6.0 \mathrm{mg} / 1$ \\
\hline Manganese & $0.132 \mathrm{mg} / 1$ & $0.08 \mathrm{mg} / 1$ \\
\hline $\begin{array}{c}\text { Alkalinity and } \\
\text { bicarbonates }\end{array}$ & $126 \mathrm{mg} / 1$ & $120 \mathrm{mg} / 1$ \\
\hline \multicolumn{3}{|c|}{ Table 4: Physiochemical analysis. } \\
\hline
\end{tabular}

The heat and oxidation of the nanotubes created a bluish color in the water which must be taken into consideration in future experiments.

\section{Acknowledgement}

This research was performed at school of mechanical engineering of University of San Carlos of Guatemala and Engineering Research Center (CII), USAC. Materials were provided by Kavic Engineering (Energy and Technologies) renewable energy and wastewater treatment company.

\section{References}

1. Cifuentes J (2015) Improved health by nanotechnology for water treatment, qualitative research. PhD Climate Change and Sustainability. ResearchGate 2-9.

2. Rusnano (2008) Nanomembranes technology for water filtration. Rusnano, Russia.

3. NanoCeram (2014) Nanoceramic and nanofiltration water technologies. NanoCeram, USA.

4. Rafiee J, Mi X, Gullapalli H, Thomas A, Yavari F, et al. (2012) Wetting transparency of graphene. Nat Mater 11: 217-222.

5. Mahdy A, Elkhatib E, LIN Z (2013) Effects of drinking water treatment residuals on soil solution composition and phosphorus speciation in biosolid-amended soils of Kafr El-Dawar, Egypt, and Troy, USA. Agrochimica 57: 315-336.

6. Alex PC (2010) Carbon nanotubes. Journal of Information, Technology and Society 10-14.

7. Hilder M, Winther-Jensen B, Li D, Forsyth M, MacFarlane DR (2011) Direct electro-deposition of graphene from aqueous suspensions. Physical Chemistry Chemical Physics 13: 9187-9193.

8. Osborne K (2017) Electroplating. Perry Metal Protection Ltd, Auckland, New Zealand.

9. http://www.ada2.org/sala-prensa/publicaciones/doc_view/28-coguanor-29001-99 


\section{di \\ нитар}

Journal of Anesthesia \& Clinical Care

Journal of Addiction \& Addictive Disorders

Advances in Microbiology Research

Advances in Industrial Biotechnology

Journal of Agronomy \& Agricultural Science

Journal of AIDS Clinical Research \& STDs

Journal of Alcoholism, Drug Abuse \& Substance Dependence

Journal of Allergy Disorders \& Therapy

Journal of Alternative, Complementary \& Integrative Medicine

Journal of Alzheimer's \& Neurodegenerative Diseases

Journal of Angiology \& Vascular Surgery

Journal of Animal Research \& Veterinary Science

Archives of Zoological Studies

Archives of Urology

Journal of Atmospheric \& Earth-Sciences

Journal of Aquaculture \& Fisheries

Journal of Biotech Research \& Biochemistry

Journal of Brain \& Neuroscience Research

Journal of Cancer Biology \& Treatment

Journal of Cardiology \& Neurocardiovascular Diseases

Journal of Cell Biology \& Cell Metabolism

Journal of Clinical Dermatology \& Therapy

Journal of Clinical Immunology \& Immunotherapy

Journal of Clinical Studies \& Medical Case Reports

Journal of Community Medicine \& Public Health Care

Current Trends: Medical \& Biological Engineering

Journal of Cytology \& Tissue Biology

Journal of Dentistry: Oral Health \& Cosmesis

Journal of Diabetes \& Metabolic Disorders

Journal of Dairy Research \& Technology

Journal of Emergency Medicine Trauma \& Surgical Care

Journal of Environmental Science: Current Research

Journal of Food Science \& Nutrition

Journal of Forensic, Legal \& Investigative Sciences

Journal of Gastroenterology \& Hepatology Research
Journal of Gerontology \& Geriatric Medicine

Journal of Genetics \& Genomic Sciences

Journal of Hematology, Blood Transfusion \& Disorders

Journal of Human Endocrinology

Journal of Hospice \& Palliative Medical Care

Journal of Internal Medicine \& Primary Healthcare

Journal of Infectious \& Non Infectious Diseases

Journal of Light \& Laser: Current Trends

Journal of Modern Chemical Sciences

Journal of Medicine: Study \& Research

Journal of Nanotechnology: Nanomedicine \& Nanobiotechnology

Journal of Neonatology \& Clinical Pediatrics

Journal of Nephrology \& Renal Therapy

Journal of Non Invasive Vascular Investigation

Journal of Nuclear Medicine, Radiology \& Radiation Therapy

Journal of Obesity \& Weight Loss

Journal of Orthopedic Research \& Physiotherapy

Journal of Otolaryngology, Head \& Neck Surgery

Journal of Protein Research \& Bioinformatics

Journal of Pathology Clinical \& Medical Research

Journal of Pharmacology, Pharmaceutics \& Pharmacovigilance

Journal of Physical Medicine, Rehabilitation \& Disabilities

Journal of Plant Science: Current Research

Journal of Psychiatry, Depression \& Anxiety

Journal of Pulmonary Medicine \& Respiratory Research

Journal of Practical \& Professional Nursing

Journal of Reproductive Medicine, Gynaecology \& Obstetrics

Journal of Stem Cells Research, Development \& Therapy

Journal of Surgery: Current Trends \& Innovations

Journal of Toxicology: Current Research

Journal of Translational Science and Research

Trends in Anatomy \& Physiology

Journal of Vaccines Research \& Vaccination

Journal of Virology \& Antivirals

Submit Your Manuscript: http://www.heraldopenaccess.us/Online-Submission.php 